\title{
Pengembangan Media Pembelajaran Handout Digital Berbasis Android
}

\author{
Devangga Putra Adhitya Pratama*1, Norida Canda Sakti ${ }^{2}$ \\ Program Studi Pendidikan Ekonomi \\ Universitas Negeri Surabaya \\ Surabaya, Indonesia
}

e-mail: devanggap.16080554001@mhs.unesa.ac.id ${ }^{* 1}$, noridacanda@unesa.ac.id²

Pengutipan:

Pratama, D.P.A \&

Sakti, N.C.

(2020).

Pengembangan

Media

Pembelajaran

Handout Digital

Berbasis Android.

Jurnal Pendidikan

Ekonomi

Undiksha, 12 (1),

15-28

\begin{abstract}
Abstrak
Riwayat Artikel Tanggal diajukan: 8 Juni 2020

Tanggal diterima : 13 Juni 2020

Tanggal dipublikasikan: 29 Juni 2020 Penelitian ini didasari karena adanya celah dari media pembelajaran yang ada
berupa powerpoint ketika digunakan pada bahasan materi yang dirasa kompleks. Pengembangan media pembelajaran memiliki tujuan untuk menentukan kelayakan, tanggapan dan hasil belajar siswa pada media pembelajaran digital handout berbasis android. Penelitian ini dilaksanakan pada 20 peserta didik kelas XI di SMA Negeri 1 Puri Mojokerto dengan cara wawancara, dokumentasi, dan angket yang dianalisis melalui analisis data kualitatif dan kuantitatif. Model penelitian menggunakan 4D dengan tahapan pendefinisian, perancangan, pengembangan, dan penyebaran. Luaran penelitian yaituaplikasi media pembelajaran handout digital berbasis android dengan format APK. Hasil validasi penelitian ini memperoleh simpulan sangat layak dengan rincian ahli materi $92,8 \%$, ahli media87,8\%, ahli evaluasi $84 \%$ dan ahli soal $88 \%$. Peserta didik menghasilkan respon positif dengan hasil $91,8 \%$ dan memicu terjadinya peningkatan hasil belajar yang cenderung tinggi dilihat dari nilai rata-rata Gain Score sejumlah 0,71 dengan ketuntasan klasikal posttest $90 \%$. Maka, dapat disimpulkan bahwa media pembelajaran handout digital dapat mempermudah pemahaman peserta didik melalui media yang layak dengan respons positif dan mampu meningkatkan hasil belajar.
\end{abstract}

Kata kunci: handout digital; berbasis android; media pembelajaran.

\begin{abstract}
This research is based on the existence of gaps in the Powerpoint learning media when used in complex material discussions. The development of instructional media has the aim to determine the feasibility, find out responses and learning outcomes of student on digital handout learning media based on androidThis research was conducted to 20 students of class XI in the 1st Senior High School Puri Mojokerto by collecting data using interviews, documentation, and questionnaires that were analyzed through qualitative and quantitative data analysis. The research model utilized 4D consisting of define, design, develop, and disseminate stages. The outputs of research were Android-based digital handout learning media applications with the APK format. The validation results of Digital Handout media obtained proper conclusions with the details, i.e., material experts by $92.8 \%$, media experts by $87.8 \%$, evaluation experts by $84 \%$, and question experts by $88 \%$. Students resulted in the positive responses by $91.8 \%$ and induced an increase in learning outcomes, which relatively high, considering from an average Gain Score of 0.71 with the completeness of classical posttest amounting to $90 \%$. Therefore, it can be concluded that based on the results, digital handout learning media can facilitate students' understanding through appropriate media with positif responsses and increase in learning outcomes.
\end{abstract}

Keywords : digital handout; based on android, learning media 


\section{PENDAHULUAN}

Proses pembelajaran memerlukan bantuan dari media berbasis teknologi untuk menjadi fasilitas penyalur informasi dan memperluas jangkauan pembelajaran membuat kegiatan belajar mengajar dengan media dapat membuka batasan pembelajaran untuk mendukung peserta didik belajar kapan saja di mana saja Kularbphettong, Putglan, Tachpettong, Tongsiri, \& Roonrakwit (2015). Hal ini juga akan mendapat hasil yang optimal apabila media pembelajaran yang digunakan dapat mengikuti perkembangan teknologi saat ini. Selaras dengan yang diungkapkan oleh Suryani, Setiawan \& Putria (2018) bahwa media pembelajaran memiliki fungsi untuk membangun suasana belajar dengan tanpa tekanan dan menyenangkan. Salah satunya dengan menciptakan media pembelajaran yang memiliki desain dan inovasi baru dengan penyesuaian padapokok bahasan dan karakteristik peserta didik sendiri agar meningkatkan rasa ingin tahu terhadap materi yang nantinya dapat berpengaruh besar pada partisipasi peserta didik.

Berdasarkan kegiatan observasi yang telah dilakukan di SMA Negeri 1 Puri Mojokerto dengan beberapa peserta didik yang ditunjuk untuk mewakili kelasnya masing-masing mulai dari XI IPS 1 hingga XI IPS 4 terkait dengan kendala yang dialami selama pembelajaran. Kendala pembelajaran biasa muncul ketika materi ajar cukup banyak yang harus dipelajari dan diminta untuk memahaminya membuat peserta didik harus mencatat kembali materi yang disampaikan oleh guru.Hal ini membuat peserta didik sempat memberi masukan untuk mencoba dengan media pembelajaran yang bisa digunakan pada handphone. Melihat keinginan peserta didik dalam mencoba menggunakan media pembelajaran melalui handphone, berikut daftar pengguna handphone yang terdapat di kelas XI IPS, yaitu:

Tabel 1. Daftar Pengguna Android Kelas XI IPS

\begin{tabular}{cccccc}
\hline No. & Kelas & $\begin{array}{c}\text { Jumlah } \\
\text { Peserta } \\
\text { Didik }\end{array}$ & $\begin{array}{c}\text { Pengguna } \\
\text { Android }\end{array}$ & $\begin{array}{c}\text { Pengguna } \\
\text { iOS }\end{array}$ & $\begin{array}{c}\text { Pengguna } \\
\text { Sistem } \\
\text { Operasi } \\
\text { Handphone } \\
\text { Lain }\end{array}$ \\
\hline 1. & XI IPS 1 & 32 & 30 & 2 & - \\
2. & XI IPS 2 & 31 & 28 & 3 & - \\
3. & XI IPS 3 & 32 & 29 & 3 & - \\
4. & XI IPS 4 & 32 & 30 & 2 & - \\
\hline
\end{tabular}

Sumber: diolah Peneliti, (2019)

Pemilihan media pembelajaran digital yang berbasis android dilakukan mengacu pada penggunaan bahan ajar dengan isi materi yang sesuai dengan standar kompetensi dan juga lebih menarik perhatian peserta didik dengan mayoritas adalah pengguna handphoneberplatform android dengan versi 4.1 JellyBean sampai 9.0 Pie. Versi ini memiliki fitur yang lebih memungkinkan untuk dijalankannya aplikasi baru yang dibuat bukan dari produsennya. Penggunaan tipe media handphone android berdasarkan observasi yang dilakukan peneliti dengan hasil $93 \%$ peserta didik memiliki handphone android, $7 \%$ peserta didik mempunyai handphone Iphone, dan tidak ada peserta didik yang menggunakan handphone merk lain dirasa cukup menunjang kebutuhan peserta didik untuk belajar.

Berdasarkan dukungan hasil studi pendahuluan di SMA Negeri 1 Puri Mojokerto, peneliti menemukan kendala pada kemampuan optimalisasi powerpoint pada pelaksanaan pembelajaran di kelas. Karena pada dokumentasi serta pengamatan di lapangan menyatakan bahwa media papan tulis dan powerpoint masih menjadi pilihan utama untuk meningkatkan pemahaman peserta didik.

Media powerpoint dinilai oleh sebagian besar guru dapat membantu guru dalam menjelaskan materi yang belum bisa dipahami peserta didik yang terdapat pada 
buku teks. Kelebihan tersebut didukung oleh penelitian Andriani \& Wahyudi (2016) dengan temuan penelitian media pembelajaran powerpoint interaktif sangat efektif untuk digunakan karena semua hal yang tidak dapat dijangkau atau sulit untuk disajikan secara nyata dapat disajikan sebagai bahan ajar dan dapat membuat peserta didik merasa senang serta lebih fokus mengikuti pembelajaran sehingga pengondisian kelas saat pembelajaran menjadilebih mudah. Hasil penelitian tersebut juga selaras dengan yang dikemukakan oleh Srimaya dalam Nurhidayati, Asrori, Ahsanuddin, \& Dariyadi (2019) bahwa media powerpoint yang digunakan saat kegiatan belajar mampu mengefektifkan motivasi, keaktifan, dan hasil belajar dengan memuat konsep abstrak yang disajikan menjadi lebih konkrit melalui cara visualisasi.

Powerpoint merupakan media yang dengan banyak kelebihan untuk pembelajaran. Namun apabila dilihat pada pengamatan penggunaan media papan tulis dan powerpoint SMA Negeri 1 Puri Mojokerto, kelebihan yang dimiliki powerpoint tersebut belum bisa diterapkan dengan baik dengan pembuatannya yang sangat sederhana tanpa adanya desain yang menarik dan inovatif yang belum mampu membuat peserta lebih mudah memahami materi dan bisa belajar mandiri. Karena standar tampilan ideal powerpoint menurut Rahayu (2012) memiliki isi kurang dari 45 kata dalam setiap slide dengan standar ukuran huruf minimal yang mudah dibaca adalah Arial 24pt. Materi yang terdapat dalam powerpoint hanya berupa poin inti saja sehingga belum bisa mewakili penjelasan materi untuk membuat peserta didik memahami kompleksnya materi sesuai dengan pengetahuan yang diberikan oleh guru. Oleh karena itu, keterampilan khusus dibutuhkan dalam menuangkan pesan atau materi yang baik pada powerpoint sehingga mudah dicerna oleh penerima pesan karena powerpoint didesain berbentuk slide yang berisi poin-poin materi dengan penjelasan bergantung pada narasumber. Serupa dengan pendapat dari Andriani \& Wahyudi (2016) dengan masih ditemukan kelemahan dari powerpoint yang tidak serba cocok apabila diterapkan semua jenis dan tujuan pembelajaran

Seperti halnya yang dijelaskan oleh bapak Deby Ruli Sandi, S.Pd yang berprofesi sebagai pengajar ekonomi kelas XI IPS di SMAN 1 Puri Mojokerto mengatakan dari pengalaman mengajar materi APBN dan APBD yang memerlukan banyak sumber bahasan dan kuantitas pertemuan yang lebih intens karena bahasan materi dirasa lebih kompleks. Maka perlu adanya pusat sumber belajar yang menyediakan sumber-sumber belajar (learning resources) seperti bahan belajar cetak dan non cetak, serta sumber manusiawi dalam membentuk pengembangan sistem instruksional. Selaras dengan tujuan pusat sumber belajar menurut Warsita (2008) sebagai preskripsi (petunjuk) agar peserta didik mudah belajar dalam mencapai tujuan pembelajaran.

Berdasarkan penjelasan tersebut apabila ditinjau dari teori belajar, materi APBN dan APBD akan sesuai apabila menggunakan teori konstruktivisme sosial Vygotsky. Karena apabila melihat pokok bahasan materi yang banyak dan lebih kompleks, Slavin dalam Trianto (2014) skema ajar lebih cocok menggunakan pendekatan konstruktivis dengan intensitas pembelajaran kooperatif yang lebih tinggi. Hal ini berdasar pada membantu peserta didik agar lebih mudah saat menemukan dan memahami konsep-konsep yang sulit jika mereka mampu saling berdiskusi dengan temannya terkait dengan studi kasus atau masalah. Peran guru pada teori konstruktivisme dalam Suprijono, (2015) untuk menetapkan tugas, pertanyaan, dan menyediakan bahan serta informasi yang dirancang untuk membantu peserta didik menyelesaikan masalah yang dimaksud. Harapan dari pengembangan media yang menyediakan informasi dan bahan-bahan belajar yang didukung teori konstruktivisme melalui interaksi sosial membuat peserta didik lebih mudah dalam memahami materi yang diajarkan sehingga dapat meningkatkan hasil belajarnya.

Menurut pandangan Vygotsky dalam Danaoebroto (2015) tentang konstruktif juga perlu adanya sumber belajar lain untuk memudahkan peserta didik dalam belajar serta disesuaikan dengan materi dan 
kapasitas peserta didik itu sendiri. Maka, juga perlu adanya teori belajar pendukung yang cocok untuk melengkapi skema belajar konstruktivisme sosial Vygotsky tersebut yaitu dengan menerapkan teori belajar Robert M. Gagne. Pandangan belajar menurut Gagne dalam Warsita (2008) hendaknya mampu menimbulkan peristiwa belajar (instructional events) dengan urutan yaitu: (1) menimbulkan minat dan memusatkan perhatian agar peserta didik siap menerima pelajaran; (2) menyampaikan tujuan pembelajaran; (3) mengingat kembali konsep yang telah dipelajari sebelumnya; (4) menyampaikan materi pembelajaran; (5) memberikan bimbingan atau pedoman untuk belajar; (6) membangkitkan timbulnya unjuk kerja peserta didik; (7) memberikan umpan balik tentang kebenaran pelaksanaan tugas (penguatan); (8) mengevaluasi hasil belajar; dan (9) memperkuat retensi dan transfer belajar. Gagne meyakini belajar tidak hanya mementingkan pada hasil tetapi juga mementingkan sistem informasi yang diolah dalam sumber belajar secara sistematis dan melembaga dalam bentuk Pusat Sumber Belajar (PSB) atau Learning Resources Centre (LRC). Sehingga peneliti mencoba mengakomodasi teori belajar model nine instructional events Gagne ke dalam pengembangan media yang ada pada menumenu utama.

Media pembelajaran yang dirasa sesuai untuk diterapkan adalah media pembelajaran handout dengan tampilan digital yang bisa digunakan pada handphone berplatform android. Kegunaan handout menurut Prastowo (2015) dapat mempermudah peserta didik dengan memberikan bantuan informasi sebagai pegangan dan dapat pula melengkapi kekurangan materi yang diberikan dalam buku teks maupun yang disampaikan secara lisan oleh guru. Media pembelajaran elektronik dapat diaplikasikan apabila peserta didik mengalami kesulitan dalam memahami materi ajar yang disajikan guru dengan tatap muka. (Sudarsana, 2018)

Didukung dengan definisi handout menurut Mohammad dalam Prastowo (2015) yang memaknai handout sebagai selembar atau beberapa lembar kertas yang diberikan kepada peserta didik berupa ringkasan suatu topik, tugas, atau tes. Maka, keunggulan handout yang menjadi bahan pembelajaran terperinci dan ringkas membuat penggunaan handout akan mengurangi verbalitas materi yang disampaikan sehingga materi handout langsung pada penjelasan yang harus dipahami dan mampu meningkatkan peran aktif peserta didik karena memberikan kesempatan bagi peserta didik dapat belajar mandiri diluar jam pelajaran.

Adapula penelitian yang relevan dengan pengembangan media pembelajaran handout berbasis android, Oktaviana \& Susilowibowo (2017) dengan hasil penelitian berupa produk dengan memasukkan komponen penunjang seperti: materi, latihan soal, glosarium, desain background, logo aplikasi, simbol menu utama ke dalam handout melalui bahasa pemrograman dapat membuat peserta didik lebih antusias, termotivasi untuk menambah wawasansehingga dianjurkan untuk digunakan sebagai pendukung bahan ajar pada materi akuntansi persediaan. Kemudian hasil tersebut selaras dengan penjabaran dari Prastowo (2015) apabila bahan ajar tersedia secara bervariasi, inovatif, dan menarik, maka ada tiga kegunaan bahan ajar bagi peserta didik yaitu kegiatan pembelajaran menjadi lebih menarik, peserta didik lebih banyak mendapatkan kesempatan untuk belajar secara mandiri dengan bimbingan pendidik, dan peserta didik mendapatkan kemudahan dalam mempelajari setiap kompetensi yang harus dikuasainya.

Perbedaan powerpoint dengan handout terletak pada tampilan powerpoint mengedepankan slide, sedangkan handout digital didesain dengan tampilan menu dengan pengoperasian scoll up dan scroll down. Adapula teknik umpan balik dan evaluasi yang terdapat pada powerpoint biasanya ditampilkan pada LCD proyektor dan pengoreksian dilakukan secara manual, sedangkan pada handout digital menggunakan tampilan multiple choice dengan menyediakan tombol yang bisa dipilih dan dapat diketahui nilai akhir setelah pengerjaan disertai mode setting durasi pengerjaan. Pertimbangan lain dari segi isi, powerpoint berisi point-point penting yang nanti akan dijelaskan lebih lanjut oleh narasumber atau guru, sedangkan pada handout menurut Prastowo (2015) berisi 
ringkasan inti materi yang langsung disertai dengan penjelasannya untuk mempermudah pemahaman dari peserta didik sendiri.

Luaran berupa produk berbentuk aplikasi berbasis android berupa media pembelajaran digital dengan unsur-unsur handout mampu digunakan oleh pengajar dalam menunjang kegiatan belajar di kelas. Seperti hasil penelitian dari Luna-Nevarez (2018) pembelajaran menggunakan media digital dan aplikasi selular memiliki tingkat kemenarikan menjadi lebih tinggi dan kinerja peserta didik saat menyelesaikan tugas menjadi lebih baik.

Penerapan media pembelajaran dengan adanya pengembangan melalui adaptasi unsur-unsur handoutyang ditampilkan dalam bentuk aplikasi android ini, memiliki hal baru dengan optimalisasi kemampuan media terdapat pada menu kuis formatif yang di dalamnya terdapat soal multiple choice yang bisa diketahui nilai dan apabila peserta didik salah dalam menjawab soal terdapat umpan balik berupa penyebutan materi yang harus dipelajari kembali. Pengembangan ini diharapkan mampu memberikan kontribusi dalam efisiensi saat mengevaluasi kemampuan peserta didikterhadap materi ajar yang banyak dan mengatasi kekurangan media pembelajaran yang sudah ada sekaligus dapat menjadi alat untuk menguatkan pemahaman peserta didik. Dengan begitu media ini dapat menunjang bahan ajar yang telah tersedia untuk mempermudah kegiatan pembelajaran, serta bisa menjadi alternatif media yang beradaptasi dengan gaya belajar peserta didik untuk lebih aktif dan tercipta suasana belajar yang menarik dan menyenangkan saat pembelajaran ekonomi dengan kelebihan-kelebihan yang akan ditawarkan.

Berdasarkan uraian latar belakang di atas dengan didukung pendapat ahli dan penelitian terdahulu, perlu dilakukan penelitian atas dasar permasalahan pengelolaan media dalam materi APBN dan APBD yang masih bisa dioptimalkan supaya dalam pertemuan selanjutnya dapat menambah ketuntasan klasikal peserta didik di akhir semester. Sehingga tujuan yang hendak dicapai dalam penelitian ini yaitu: 1) Menganalisis kelayakan media pembelajaran handout digital berbasis android; 2) Menganalisis respons peserta didik terhadap media pembelajaran handout digital berbasis android; 3) Menganalisis hasil belajar peserta didik terhadap media pembelajaran handout digital berbasis android. Maka untuk mengkaji masalah yang muncul tersebut, peneliti akan melakukan penelitian dengan judul "Pengembangan Media Pembelajaran Handout Digital sebagai Penunjang Bahan Ajar Berbasis Android pada Materi APBN dan APBD Kelas XI IPS SMA Negeri 1 Puri Mojokerto". Hasilnya diharapkan muncul solusi pada media pembelajaran baru berbentuk aplikasi android melalui validasi kelayakan materi, media, evaluasi dan soal yang dapat diterapkan dengan tepat pada materi APBN dan APBD secara optimal.

\section{METODE}

Peneliti memutuskan penelitian dan pengembangan atau R\&D (Research and Development) menjadi jenis penelitian yang dipakai dalam mengembangkan produk Handout Digital ini. Menurut Sugiyono (2015) penelitian dan pengembangan atau biasa dikenal dengan istilah Research \& Development (R\&D) diartikan sebagai metode penelitian dengan fungsi mengadakan produk tertentu, dan menguji keefektifan produk tersebut. Penelitian ini berfokus pada melakukan pengembangan terhadap hasilkan produk media pembelajaran handout digital berbasis android menggunakan model 4D yang merupakan modifikasi dari Thiagarajan. Sistematika penelitian yang runtut dan jelas dan juga bisa digunakan dalam media pembelajaran di kelas membuat peneliti lebih mudah saat melaksanakan uji coba dan revisi berulang kali yang membuat model pengembangan 4D dipilih pada penelitian kali ini. Tahapan dalam pengembangan model 4D dibagi atas empat langkah antara lain: pendefinisian (define), perancangan (design), pengembangan (develop), dan penyebaran (disseminate).

Rancangan penelitian akan dijabarkan dalam prosedur penelitian agar lebih mudah mengetahui secara detail tahapan yang harus dilalui peneliti. Adapun susunan prosedur penelitian terbagi menjadi 4 tahap, tahap pendefinisian (define) yang tersusun atas 5 analisis yakni (1) analisis awal, (2) 
peserta didik, (3) konsep, (4) tugas, dan (5) perumusan tujuan pembelajaran. Tahap perancangan (design) menjadi tahapan kedua yang harus dilalui dengan 3 langkah utama yaitu (1) penyusunan tes, (2) pemilihan media disesuaikan berdasarkan tujuan pembelajaran, (3) pemilihan format.Selanjutnya adalah tahapan ketiga dalam penelitian ini yaitu tahap pengembangan (develop) yang didalamnya terdapat beberapa langkah yakni (1) telaah dan validasi perangkat oleh ahli, (2) uji coba terbatas dan lapangan pada produk, (3) revisi.Berikutnya tahapan keempat yang dilakukan peneliti adalah tahap penyebaran (disseminate) dengan menyebarkan media sehingga produk dapat dimanfaatkan di area lainnya, contohnya dilaksanakan pada lebih banyak kelas bahkan lebih banyak sekolah. Terdapat batasan penelitian pada tahap penyebaran in yaitu produk hanya disebarkan di sekolah mitra tempat dilaksanakannya penelitian uji coba produk, khususnya di kelas X, XI, dan XII IPS di SMA Negeri 1 Puri Mojokerto disertai arahan bapak/ibu guru ekonomi di sekolah tersebut.

Penelitian pengembangan media pembelajaran handout digital berbasis android difokuskan pada 20 peserta didik sebagai jumlah minimal sampel yang akan dijadikan subjek uji coba. Berkaitan dengan hal tersebut, Sadirman, Rahardjo, Haryono \& Harjito (2014) memaparkan bahwa target populasi yang diwakilkan pada penelitian perlu dilakukan uji coba media kepada 10-20 peserta didik. Informasi yang diperoleh akan kurang bermanfaat dalam evaluasi kelompok kecil apabila jumlah data yang diolah melebihi dua puluh. Sedangkan perolehan data dikatakan kurang menggambarkan populasi target apabila mendapatkan data dari responden dengan jumlah kurang dari sepuluh.

Model 4D pada penelitian pengembangan media handout digital berbasis android ini memiliki tahapan penelitian dengan kerangka sebagai berikut:

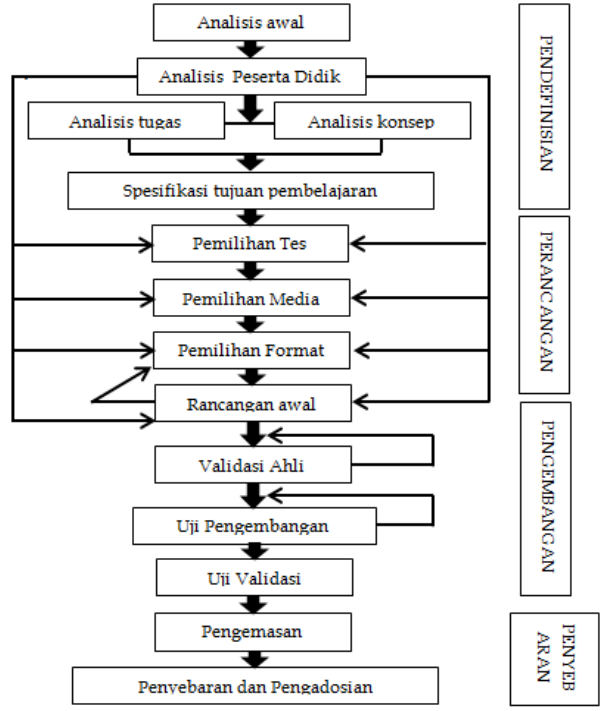

Gambar 1. Model Pengembangan

Perangkat Pembelajaran 4D Sumber: Trianto (2014)

Pemilihan dilakukan secara sistematis dengan pengambilan berdasar dari penetapan tanda-tanda khusus seperti populasi kelas dengan pengguna handphone android yang lebih dominan ada di XI IPS 1 dengan 30 dari 32 peserta didik dan memenuhi kriteria ciri-ciri peserta didik dengan kemampuan kognitif terbaik dan kurang baik akibat dari penggunaan media sebelumnya yang lebih beragam. Sampel yang dipilih telah diserasikan dengan tujuan penelitian sehingga mampu menjawab permasalahan yang diteliti yaitu menganalisis penggunaan media pembelajaran yang telah dinyatakan tepat sehingga membuat peserta didik memiliki respons terhadap materi yang diajarkan menjadi lebih mudah untuk dipahami dan terjadi perubahan hasil belajar kearah yang lebih baik.

Oleh karena itu, peneliti menggunakan teknik purposive sampling karena menurut Sugiyono (2015) penggunaan teknik sampel berdasarkan pertimbangan kriteria tertentu supaya proses pengambilan sampel dapat dilakukan secara tidak acak. Hal ini dilakukan agar sampel yang diambil dapat sesuai dengan kriteria dan bisa memberikan data yang relevan dengan tujuan penelitian.Maka untuk mendukung hal tersebut, media yang diujicobakan dalam penelitian pengembangan ini menggunakan 
desain uji coba yaitu Pre-Experimental design dengan model One Group PretestPosttest Design.

$$
\mathrm{O}_{1} \longrightarrow \mathrm{X} \longrightarrow \mathrm{O}_{2}
$$

Gambar 2.One Group Pretest-Posttest Design

Sumber: Sugiyono (2015)

Keterangan:

01 : Analisis nilai pretest peserta didik sebelum diberi media handout digital

$X$ : Pemberian treatment dengan media handout digital berbasis android

$\mathrm{O} 2$ : Analisis nilai posttest peserta didik akibat diberi media handout digital Teknik pengumpulan data menggunakan instrumen pengembangan sebagai berikut: (1) lembar wawancara studi pendahuluan, (2) lembar angket telaah dan validasi meliputi materi, soal, evaluasi, dan soal yang akan dilakukan oleh tim ahli yang terdiri dari satu dosen pendidikan ekonomi selaku ahli materi ekonomi makro, satu dosen teknologi pendidikan sebagai ahli media, dan satu dosen pendidikan ekonomi yang menguasai bidang pendidikan dengan aspek ekonomi sebagai ahli evaluasi dan soal, serta satu guru ekonomi di SMA Negeri 1 Puri Mojokerto yang dirasa paham kondisi sekolah dan gaya belajar peserta didik di lingkungan belajar sekolah tersebut. (3) lembar angket respons dari peserta didik (4) lembar pretest dan posttest. Data yang telah dikumpulkan saat penelitian, kemudian akan dilakukan analisis data berupa lembar telaah untuk semua pakar memakai metode analisis deskriptif kualitatif, lembar validasi semua pakar mengadopsi sistem perhitungan skala likert, analisis respons peserta didik mengadopsi sistem perhitungan skala Guttman, dan analisis hasil belajar menerapkan kriteria gain skor.

Adapun spesifikasi produk dari pengembangan media Handout digital berbasis android yang digunakan sebagai alat penelitian yakni: (1) Media handout digital dibuat memanfaatkan software online App Inventor dengan hasil berbentuk media aplikasi yang bisa diakses pada handphone android. (2) Ukuran media handout digital tersedia pada layar handphone 4.7-6.0 inchi.
(3) Media pembelajaran handout digital memiliki 8 menu utama yaitu: petunjuk belajar, pendahuluan, materi belajar, video belajar, evaluasi belajar, quiz formatif, glosarium atau kata kunci, dan daftar rujukan. Media juga memiliki 3 submenu seperti: handout informasi, kompetensi dasar, dan peta konsep. (4) Setiap menu memiliki simbol yang berbeda supaya dapat dengan mudah membedakannya.

Tersedianya menu glosarium atau kata kunci untuk mempermudah memahami inti materi yang diajarkan. (6) Materi dilengkapi dengan gambar, rumus, hingga video pembelajaran guna menciptakan variasi literasi di dalamnya. (7) Latihan soal dibuat dalam bentuk multiple choicedan dapat dilihat nilai diakhir pengerjaan serta memiliki durasi waktu pengerjaannya. (8) Tersedianya daftar rujukan sebagai petunjuk sumber bacaan bahan ajar utama yang relevan.

\section{HASIL DAN PEMBAHASAN \\ Hasil}

Peneliti memeroleh hasil penelitian dengan memakai perangkat pengembangan model 4D berdasarkan pendapat dari Thiagarajan \& Sivasailan (1974) model tersebut terdapat 4 langkah prosedural yakni: pendefinisian (define), perancangan (design), pengembangan (develop), dan penyebaran (disseminate).

Rincian langkah penelitian model pengembangan 4D pada tahap pendefinisian (define) melakukan analisis awal dengan temuan saat observasi yaitu penggunaan media pembelajaran powerpoint yang diterapkan pada materi APBN dan APBD kelas XI berdasar pada pengalaman guru ekonomi dirasa kurang tepat karena memerlukan banyak poin bahasan yang bersifat deklaratif dan prosedural yang harus dijelaskan secara runtutsehingga materi ini memiliki kuantitas pertemuan yang lebih intens dibanding dengan materi yang lain. Jika dihubungkan dengan aplikasi, maka materi yang kompleks ini akan sepadan dengan manfaat handout Astuti, Ashari \& Kurniawan (2018) dengan isi penjelasan materi yang lebih singkat dengan cara menjabarkan kaitan antartopik, menyampaikan pertanyaan dan apa yang harus dilakukan kepada peserta Selanjutnya, analisis peserta didik dimana 
peneliti menemukan hasil observasi yaitu 93\% peserta didik memiliki handphone android, $7 \%$ peserta didik mempunyai handphone Iphone, dan tidak ada peserta didik yang menggunakan handphone merk lain. Adapun dalam analisis tugas dan perumusan tujuan pembelajaran, peneliti menemukan 13 indikator kompetensi beserta rumusan tujuan pembelajaran dari hasil identifikasi KD 3.6 dengan materi APBN dan APBD.

Pada analisis konsep terdapat pertimbangan banyaknya indikator pokok bahasan yang ingin disampaikan oleh guru. Maka, peneliti menggunakan konsep dari unsur-unsur yang terkandung pada handout yang meliputi: standar kompetensi, kompetensi dasar, latihan soal yang dapat diketahui nilai dan evaluasinya, glosarium atau kata kunci untuk mempermudah memahami inti materi, sumber bacaan yang relevan sebagai bahan ajar utama, dan materi yang dilengkapi dengan gambar, rumus, hingga video pembelajaran.

Tahapan kedua yang harus dilakukan adalah perancangan (design) dengan melakukan persiapan pada konsep yang telah diperoleh kemudian diwujudkan dengan rancangan media.Rancangan yang di dapat adalah pembuatan media pembelajaran berbasis android dengan isi materi APBN dan APBD yang didesain dengan konsep menu-menu hasil adopsi dari unsur-unsur handout. Kegiatan yang dilakukan pada tahap ini yaitu: a) Melakukan analisa format-format perangkat pembeljaran yang sudah ada, b) Menentukan judul handout dan disesuaikan dengan kompetensi dasar serta materi pokok yang akan dicapai, c) Merancang perangkat pembelajaran yang berisi dalam bentuk silabus, Rencana Pelaksanaan Pembelajaran (RPP), tujuan pembelajaran, materi ajar, dan tugas yang mengarahkan peserta didik pada evaluasi diri dalam belajar, d) Mengumpulkan berbagai referensi (desain gambar dan studi kasus) terkini dan relevan dengan materi APBN dan APBD sebagai bahan penulisan dan untuk di ditampilkan dalam perangkat pembelajaran, e) Menuis handout dan mendesain tampilan perangkat pembelajaran, f) Evaluasi hasil tulisan dengan cara baca ulang dan melakukan telaah ahli materi, g) Merevisi handout sesuai dengan kekurangan yang ditemukan, h) Implementasi handout dalam media pembelajaran dengan dukungan sumber belajar yang dapat memperkaya materi handout seperti: buku paket, LKS, dan sumber internet yang relevan.

Tahap ketiga yakni pengembangan (develop) dengan produk berupa media telah mengalami proses pengembangan dari acuan yang telah dibuat. Tahap ini produk mengalami pembaruan desain menjadi 9 menu utama dan 3 submenu hasil adopsi dari unsur-unsur handout yang secara umum di dalamnya terdapat kombinasi materi, gambar, dan video pembelajaran. Optimalisasi kemampuan media dengan format aplikasi juga terdapat pada menu kuis formatif yang di dalamnya terdapat soal multiple choice yang bisa diketahui nilai dan apabila peserta didik salah dalam menjawab soal terdapat umpan balik berupa penyebutan materi yang harus dipelajari kembali.

Proses pengembangan media ini dikenakan penilaian dari tim ahli dimasingmasing bidang materi, media, evaluasi, dan soal berupa komentar atau saran yang dirujuk dari hasil telaah yang kemudian menjadi patokan untuk menyempurnakan media handout digital. Dari uji materi yang telah dilakukan oleh ahli materi diperoleh saran untuk menggunakan format yang sesuai dengan panduan dan menyederhanakan petunjuk belajar agar materi lebih mudah dibaca dan mudah dipahami. Sementara itu, Ahli media menyarankan susunan menu diubah sehingga menjadi terlihat seutuhnya dan warna tampilan dibuat lebih terang dan menarik.Adapun saran dari ahli evaluasi dan soal terkait dengan mengubah dominasi warna latar belakang menjadi putih dan menambah sumber gambar pada soalserta memperbaiki kalimat pertanyaan pada soal sehingga tidak terlalu panjang dan lebih sederhana.

Setelah melalui tahap revisi telaah dan media handout digital telah dikatakan layak oleh tim ahli, hasil tersebut akan dikombinasikan dengan langkah uji coba terbatas pada 20 peserta didik kelas XI IPS yang sedang menjalani pembelajaran materi APBN dan APBD. Uji coba terbatas tersebut, dilakukan dengan maksud melihat respons 
melalui angket dan hasil belajar melalui pretest hingga posttest dari peserta didik setalah diterapkannya aplikasi handphone android berupa handout digital sebagai media pembelajaran.

Tahap keempat yang terdapat dalam model 4D yaitu penyebaran (disseminate). Tahap ini peneliti mengharapkan publisitas sebuah produk pengembang dapat dipergunakan pengguna. Merujuk pendapat Thiagarajan \& Sivasailan (1974) yang menyebutkan adanya tahap vital namun lebih sering terabaikan yaitu tahap pengemasan akhir, difusi, dan adopsi. Adapun dalam melakukan penyebaran, terdapat perhatian khusus yang perlu diperhatikan peneliti yakni analisis pengguna. Peneliti melakukan batasan penelitian untuk menyebarkan produk hanya di tempat sekolah yang diteliti dengan tambahan kelas X, XI, dan XII di SMA Negeri 1 Puri Mojokerto. Peneliti memiliki pertimbangan bahwa peserta didik di SMA tersebut dipilih karena memiliki budaya yang mirip dengan subjek yang diteliti sehingga penyebaran memiliki batasan khusus pada peserta didik di SMAN 1 Puri Mojokerto. Predikat peserta didik yang akan, sedang, dan telah menempuh mata pelajaran APBN dan APBD menjadi alasan peneliti menyebarkan produk tidak pada seluruh peserta didik di SMA tersebut.

\section{Pembahasan}

Kelayakan media pembelajaran handout digital berbasis android

Penentuan kelayakan media dalam penelitian ini berdasar pada tolok ukur dari perolehan data hasil validasi yang dilakukan oleh validator tim ahli. Menurut Walker \& Hess dalam Arsyad (2014) menguraikan pendapatnya terkait penerapan beberapa standar untuk mengulas media yang merujuk pada kualitas dapat menggunakan aspek kualitas isi dan tujuan, kualitas instruksional, dan kualitas teknis.

Data yang berbentuk deskriptif kuantitatif berisi aspek yang telah divalidasi dan dinyatakan dalam data berwujud angka.Kemudian dilakukan identifikasi dan penjabaran lebih lanjut sehingga mendapatkan analisa berupa kalimat uraian yang dapat menyatakan bahwa media yang dikembangkan telah dikategorikan layak oleh para ahli validasi.

Penilaian yang telah dilaksanakan oleh tim ahli validasi materi menemukan hasil pengujian kelayakan atas materi APBN dan APBD. Dengan menilik data yang telah diterima peneliti berupa rekapitulasi hasil validasi materi mengarah pada nilai aspek yang diteliti dengan rincian hasil antara lain: kualitas isi dan tujuan mencapai hasil $90 \%$, kualitas instruksional mencapai hasil 96\%, kualitas teknis mencapai hasil $93 \%$ dan ratarata secara simultan memiliki total persentase sebesar $92.8 \%$. Oleh karena itu, peneliti melihat dari segi materi APBN dan APBD untuk kelas XI ditemukan simpulan bahwa penggunaan materi pada media handout digital berbasis android saat proses pembelajaran sudah sangat layak karena telah memenuhi kriteria kelayakan materi menurut Riduwan (2016) yakni kriteria dikatakan layak apabila nilai mencapai $\geq$ $61 \%$ dan kriteria menjadi sangat layak apabila nilai menyentuh persentase $\geq 81 \%$.

Tim ahli validasi media juga melakukan pengujian kelayakan aplikasi handout digital. Dengan berlandaskan pada data validasi oleh tim ahli, peneliti mendapat rekapitulasi dengan rincian hasil validasi media antara lain: kualitas isi dan tujuan mencapai hasil $87,5 \%$, kualitas instruksional mencapai hasil $88 \%$, kualitas teknis mencapai hasil $88 \%$ dan rata-rata persentase perhitungan simultan sebesar $87,8 \%$. Validitas yang diperoleh kemudian dicocokkan dengan kriteria validitas penelitian relevan yang dikemukakan oleh Akbar dan Sriwiyana dalam Nafis (2016) yang menyatakan bahwa media yang dikembangkan bisa dikatakan layak untuk digunakan apabila mencapai skor nilai minimal $75,01 \%$. Maka dari itu, media handout digital sudah sangat layak untuk digunakan dalam pembelajaran karena telah memenuhi kriteria kelayakan media dengan kategori nilai $\geq 75,01 \%$.

Kemudian hasil pengujian kelayakan atas metode evaluasi dan soal pada media handout digital dilakukan oleh validator ahli evaluasi dan soal.Tim validator memberikan rincian rekapitulasi hasil validasi evaluasi dan soal dengan dua nilai dari dua lembar instrumen yang berbeda. Pada uji kelayakan evaluasi, ditemukan persentase nilai ratarata $84 \%$ dari beberapa variabel yang diteliti 
meliputi: hasil $90 \%$ pada analisis kompetensi inti dan kompetensi dasar, hasil 80\% dicapai pada penyusunan kisi-kisi instrumen tes, hasil $81 \%$ penulisan dan petunjuk menjawab soal, hasil $80 \%$ pada penyusunan butir soal C1-C6, capaian $85 \%$ pada proses evaluasi hasil belajar, nilai $85 \%$ pada pemberian angka (skoring), dan persentase $90 \%$ dimiliki oleh variabel umpan balik.

Sedangkan pada kelayakan soal dengan instrumen materi mencapai hasil $90,5 \%$, konstruksi memeroleh hasil $86,6 \%$, dan bahasa mendapatkan hasil sebesar $88,7 \%$. Hal ini membuat kelayakan soal memeroleh rata-rata nilai sebesar $88 \%$. Hasil tersebut selaras dengan kualitas soal menurut Dorothy Adkins dalam Winarno (2014) yang menyampaikan bahwa persentase butir soal disertai 5 pilihan jawaban dengan kesulitan optimal $\geq 60 \%$ akan menghasilkan informasi yang maksimal sehingga dapat dipercaya dan dapat menemukan perbedaan individu dalam prestasi peserta didik.Lebih lanjut,melalui analisis item soal pilihan ganda menurut Mahjabeen et al., (2017) ditemukan tingkat kesulitan sebesar $81 \%$ dan tingkat diskriminasi sebesar $83 \%$ merupakan cara yang efektif untuk meningkatkan kualitas ujian dan dapat menilai kinerja peserta didik secara efisien.

Respons peserta didik terhadap media pembelajaran handout digital berbasis android

Sesuai pada pemaparan data angket respons, peneliti memeroleh penjelasan yaitu media pembelajaran handout digital berbasis android diberi reaksi yang beragam oleh peserta didik di setiap indikator pertanyaan. Data yang didapatkan tersebut menunjukkan bahwa 277 jawaban positif dari peserta didik merespons cara mengajar materi APBN dan APBD menggunakan media handout digital berbasis android dari total 300 jawaban positif yang memungkinkan untuk peserta didik pilih.

Penyebaran angket dengan indikator yang telah diadaptasi dari Walker \& Hess dalam Arsyad (2014) meliputi 5 aspek penilaian yaitu: kemudahan, kemenarikan, dampak bagi peserta didik, proses belajar peserta didik, dan kualitas media. Hasil dari respons peserta didik terhadap penerapan media pembelajaran yang sudah dikembangkan yaitu: persentase 95\% untuk aspek kemudahan, aspek kemenarikan dengan persentase $88 \%$, aspek dampak bagi peserta didik dengan hasil $88 \%$, aspek proses belajar peserta didik memiliki persentase $95 \%$, dan aspek kualitas media memiliki 93\%.

Merujuk pada hasil tersebut, maka ditemukan perhitungan rata-rata secara simultan sebesar $91,8 \%$ yang dinyatakan dalam kategori sangat layak atau sangat baik. Hasil tersebut sesuai apabila dibandingkan dengan temuan Saputra (2018) yang menyatakan bahwa media pembelajaran dapat dianggap praktis ketika $86,32 \%$ dari pengguna menyatakan media pembelajaran sangat bagus dan layak untuk digunakan dalam proses pembelajaran.

Hasil belajar peserta didik terhadap media pembelajaran handout digital berbasis android

Analisis hasil belajar diterapkan guna melihat perubahan yang terjadi pada pemahaman peserta didik terhadap materi ajar menggunakan media handout digital. Proses analisis dapat dilakukan dengan cara diberikannya soal berupa pretest dan juga posttest yang disertai sistem ukur untuk mengetahui perkembangan hasil belajar peserta didik.

Penggunaan sistem ukur dalam analisis hasil belajar ditujukan sebagai tolok ukur supaya hasil dapat diinterpretasikan dengan sama. Tolok ukur yang dipakai merujuk pada Permendikbud Nomor 21 Tahun 2016 yang membahas terkait ketuntasan belajar. Ketuntasan belajar yang dimaksud adalah pembelajaran dapat dinyatakan tuntas apabila peserta didik dapat mencapai lulus nilai hasil belajar sebanyak $\geq 80 \%$ dari keseluruhan peserta didik dalam satu kelas yang sama.

Nilai pretest didapat sesaat sebelum peserta didik diberikan materi menggunakan elaborasi media pembelajaran yang usai dikembangkan. Sedangkan perolehan nilai posttest ditemukan setelah penerapan media handout digital berbasis android telah usai. Dalam rangka mencaritahu peningkatan hasil belajar tersebut, peneliti melakukan uji penelitian dengan soal pretest dan posttest yang sudah divalidasi pada 20 
peserta didik kelas XI IPS 1 di SMA Negeri 1 Puri Mojokerto. Adapun tahap lanjut guna mengetahui besaran hasil belajar yang meningkat dalam sistem hitung gain score sebagai berikut:

Tabel 2. Rekapitulasi Analisis Hasil Belajar dengan Rumus Gain Score

\begin{tabular}{cccc}
\hline & \multicolumn{2}{c}{ Tes Pengetahuan } \\
\hline $\begin{array}{c}\text { Rata-rata Nilai } \\
\text { Pretest }\end{array}$ & $\begin{array}{c}\text { Rata-rata Nilai } \\
\text { Posttest }\end{array}$ & Gain Score & Kategori \\
\hline 56 & 87 & 0,71 & Tinggi \\
\hline
\end{tabular}

Sumber: diolah Peneliti, (2020)

Berdasarkan tabel 2. Rata-rata pretest yaitu 56 dan posttest 87 . Hasil belajar dengan rumus gain score memperoleh angka 0,71 yang dapat dikategorikan tinggi. Penjelasan lebih lanjut guna mempermudah melihat hasil pretest dan posttest dapat dilihat pada Gambar 3 sebagai berikut:

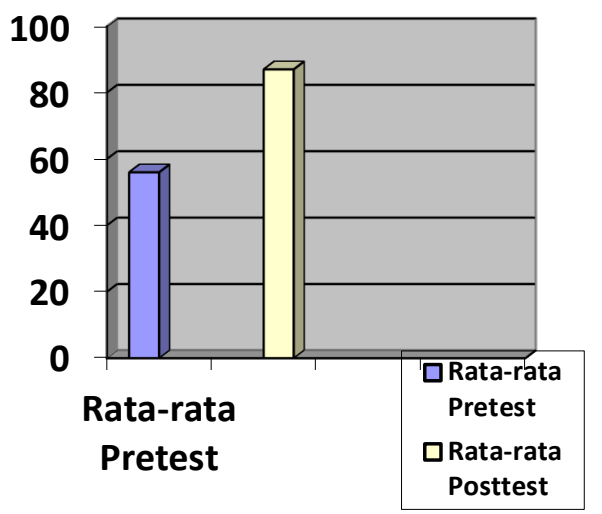

Gambar 3. Grafik Batang Hasil Belajar Sumber: diolah Peneliti, (2020)

Merujuk pada data yang terkumpul pada tabel 2 dan gambar 3, dapat ditemukan hasil dari pretest mengemukakan rata-rata nilai 20 peserta didik sejumlah 56 yang masuk pada kriteria kurang tuntas degan rincian 4 peserta didik memiliki nilai pretest $\geq$ 78 dan 16 peserta didik memiliki nilai $\leq 78$. Sehingga penilaian dalam pretest belum memenuhi kriteria ketuntasan klasikal sebesar $\geq 80 \%$. Perolehan tersebut kemudian dibandingkan dengan penilaian yang didapat pada uji posttest dimana nilai rata-rata dari 20 peserta didik menjadi 87 . Perubahan dari rata-rata nilai memiliki rincian yaitu sebanyak 18 peserta didik telah melampaui nilai Kriteria Ketuntasan Minimal (KKM) dan sebanyak 2 peserta didik masih berada di bawah nilai 78 sebagai Kriteria Ketuntasan Minimal (KKM) pada mata pelajaran ekonomi kelas XI di SMA Negeri 1
Puri Mojokerto. Dengan hasil rata-rata nilai 87 dan sebanyak 18 nilai peserta didik berada di atas KKM, peserta didik memiliki ketuntasan klasikal mencapai 90\%. Maka, dapat diinterpretasikan hasil presentase yang diperoleh menunjukkan data yang tergolong masuk pada kriteria tuntas sesuai dengan penelitian dari Syifaunnur (2015) yang mengemukakan nilai $\geq 80 \%$ sudah memenuhi kriteria ketuntasan klasikal dengan kategori sangat tuntas.

Hasil tersebut menyatakan bahwa digunakannya media handout digital dalam skema pembelajaran ini dapat meningkatkan hasil belajar yang juga didukung dari hasil analisis uji nilai Gain Score mencapai 0,71. Perolehan tersebut memiliki rincian yaitu sejumlah 10 peserta didik memiliki interval Gain Score 0,3 $\leq \mathrm{g}>0,7$ dan sisanya sebanyak 10 peserta didik mempunyai interval penilaian Gain Score $\geq 0,7$. Hasil penelitian berupa analisis uji Gain Score menggambarkan peningkatan hasil belajar yang tinggi karena terkena dampak dari penggunaan media pembelajaran yang baru. Hal ini selaras dengan penelitian relevan dari Situmorang (2015) yang menunjukkan gain score kelas yang dikenai treatment mengalami peningkatan hasil belajar materi sistem ekskresi manusia daripada kelas lain yang tidak ada treatment.

Pengklasifikasian data dalam kelompok gain membuat peneliti menjadi tahu perbedaan signifikan dari selisih hasil belajar pretest dan posttest meningkat atau menurun. Sehingga dapat menunjukkan keefektifan dari media pembelajaran handout digital berbasis android.Maka berdasar pada hasil uji penilaian pretest dan posttest dan uji nilai Gain Score dengan penelitian terdahulu bila menggunakan media handout digital berbasis android dengan beberapa tawaran kelebihan 
terdapat peningkatan tinggi dari hasil belajar menjadi signifikan setelah dilakukannya pembelajaran pada materi APBN dan APBD di kelas XI SMA Negeri 1 Puri Mojokerto.

\section{SIMPULAN DAN SARAN}

\section{Simpulan}

Merujuk pada data hasil pengembangan media pembelajaran Handout Digital berbasis Android yang telah diteliti, peneliti memeroleh simpulan: 1) Berdasarkan validasi tim ahli materi, media, evaluasi, dan soal menyatakan bahwa pengembangan media pembelajaran handout digital sebagai penunjang bahan ajar berbasis android pada materi APBN dan APBD dikategorikan sangat layak. Sehingga dapat disimpulkan bahwa handout digital dengan bentuk aplikasi handphone android yang telah dikembangkan sangat layak apabila diterapkan pada skema pembelajaran di kelas sebagai penunjang bahan ajar.; 2) Hasil dari angket respon peserta didik media pembelajaran handout digital berbasis android memperoleh kategori sangat baik dari 20 peserta didik yang berstatus sebagai subjek uji coba. Sehingga dapat disimpulkan bahwa aplikasi berbasis android berupa handout digital bermaterikan APBN dan APBD sebagai media pembelajaran yang telah dikembangkan memeroleh respon positif dari peserta didik kelas XI IPS 1 SMA Negeri 1 Puri Mojokerto; 3) Media pembelajaran handout digital dengan bentuk aplikasi handphone android dapat dinyatakan mampu memengaruhi hasil belajar peserta didik kelas XI IPS 1 MAN 1 Mojokerto menjadi lebih tinggi yang ditandai dengan tercapainya ketuntasan klasikal peserta didik dari nilai posttest sebesar $90 \%$ melewati batas persentase lulus $\geq 80 \%$ peserta didik yang berada diatas kriteria ketuntasan minimal (KKM) sekolah yaitu 78 untuk kelas XI. Sehingga dapat disimpulkan media pembelajaran handout digital dengan bentuk aplikasi handphone android yang sudah dikembangkan efektif apabila digunakan dalam skema pembelajaran di kelas.

\section{Saran}

Saran yang diberikan dengan harapan dapat menyempurnakan penelitian sebagai berikut: 1) Media dapat dikembangkan lebih lanjut mengarah pada materi di kompetensi dasar lain agar membantu peserta didik tidak hanya pada satu materi saja. Sehingga bisa membatu peserta didik dalam memahami materi secara keseluruhan yang berpengaruh padadorongan peningkatan hasil belajarnya. 2) Respon peserta didik dalam menggunakan media handut digital yang tergolong sangat positif dapat ditingkatkan dengan memasukkan konsep belajar baru dengan kesesuaianpada perkembangan teknologi yang populer dikalangan usia remaja dan kebiasaan peserta didik sendiri. 3) Penelitian selanjutnya diharapkan media diujicobakan pada peserta didik dengan jumlah yang lebih banyak dari subjek saat ini yaitu 20 peserta didik. Agar peningkatan hasil belajar berkat diterapkannya media handout digital dapat dirasakan lebih menyeluruh dan skala penelitian memiliki simpulan yang lebih luas

\section{DAFTAR PUSTAKA}

Andriani, M. R., \& Wahyudi. (2016). Pengembangan Media Pembelajaran Power Point Interaktif melalui Pendakatan Saintifik untuk Pembelajran Termatik Integratif Siswa Kelas 2 SDN Bergas Kidul 03 Kabupaten Semarang. Shcolaria, 6(1), 143-158.

Arsyad, A. (2014). Media Pembelajaran. Jakarta: Raja Grafindo Persada.

Astuti, P., Ashari, \& Kurniawan, E. S. (2018). Pengembangan Handout Fisika Berbasis Team Assisted Individualization untuk Meningkatkan Kemampuan Berpikir Kritis Peserta Didik SMA. RADIASI: Jurnal Berkala Pendidikan Fisika, 11(1), 11-16.

Danoebroto, S. W. (2015). Teori Belajar Konstruktivis Piaget dan Vygotsky. Indonesia Digital Jurnal of Mathematics and Education, 2(3), 191-198. Retrieved from http://idealmathedu.p4tkmatematika.or g/wp-content/uploads/2016/01/7_SriWulandari-D.pdf

Kularbphettong, K., Putglan, R., Tachpetpaiboon, N., Tongsiri, C., \& Roonrakwit, P. (2015). Developing of MLearning for Discrete Mathematics Based on Android Platform. Procedia - 
Social and Behavioral Sciences, 197, 793-796.

https://doi.org/10.1016/j.sbspro.2015.0 7.184

Luna-Nevarez, C., \& McGovern, E. (2018). On the Use of Mobile Apps in Education: The Impact of Digital Magazines on Student Learning. Journal of Educational Technology Systems, $\quad 47(1)$, 17-31. https://doi.org/10.1177/004723951877 8514

Mahjabeen, W., Alam, S., Hassan, U., Zafar, T., Butt, R., Konain, S., \& Rizvi, M. (2017). Analysis of Multiple Choice Questions: Item Difficulty, Discrimination Index and Distractor Efficiency. International Journal of Nursing Education, 9(3), 109. https://doi.org/10.5958/09749357.2017.00079.4

Nafis, Z. F. N. (2016). Pengembangan Media Pembelajaran Komik Audio Visual Bagi Pembelajaran Ekonomi Materi Kurs Valuta Asing di SMA Negeri 8 Malang. Jurnal Pendidikan Ekonomii, 9.

Nurhidayati, Asrori, I., Ahsanuddin, M., \& Dariyadi, M. W. (2019). Pembuatan Media Pembelajaran Berbasis Powerpoint Dan Pemanfaatan Aplikasi Android Untuk Guru Bahasa Arab. Jurnal KARINOV, 2(3), 181. https://doi.org/10.17977/um045v2i3p18 1-184

Oktaviana, P., \& Susilowibowo, J. (2017). Pengembangan Handout Berbasis Android Sebagai Pendukung Bahan Ajar untuk Mata Pelajaran Akuntansi Materi Akuntansi Persediaan Di Kelas XI Akuntansi SMK Negeri 2 Tuban. Jurnal Pendidikan Akuntansi, 2.

Prastowo, A. (2015). Panduan Kreatif Membuat Bahan Ajar Inovatif, Menciptakan Metode Pembelajaran yang Menarik dan Menyenangkan. Yogyakarta: Diva Press.

Rahayu, A. (2012). Pengaruh Media Pembelajaran dengan Power Point Terhadap Pencapaian Kompetensi Pembuatan Pola Kemeja Pria di SMK Negeri 1 Pengasih.

Riduwan. (2016). Skala Pengukuran Variabel-Variabel Penelitian. Bandung: Alfabeta.
Sadiman, A. S., Rahardjo, R., Haryono, A., \& Harjito. (2014). Media Pendidikan Pengertian, Pengembangan, dan Pemanfaatannya. Jakarta: Rajawali Press.

Saputra, M., Abidin, T. F., Ansari, B. I., \& Hidayat, M. (2018). The feasibility of an Android-based pocketbook as mathematics learning media in senior high school. Journal of Physics: Conference Series, 1088. https://doi.org/10.1088/17426596/1088/1/012056

Situmorang, R. M. (2015). Penerapan Model Pembelajaran Problem Based Learning Untuk Meningkatkan Hasil Belajar Siswa pada Materi Sisem Ekskresi Manusia. EduBio Tropika, 3, 87-90.

Sudarsana, I. K. (2018). Optimalisasi Penggunaan Teknologi dalam Implementasi Kurikulum di Sekolah (Persepektif Teori Konstruktiviame). Jurnal Ilmu Pendidikan, 1, 8-15.

Sugiyono. (2015). Metode Penelitian Kuantitatif, Kualitatif, dan R\&D. Bandung: Alfabeta.

Suprijono, A. (2015). Cooperative Learning: Teori dan Aplikasi Pakem. Yogyakarta: Pustaka Pelajar.

Suryani, N., Setiawan, A., \& Putria, A. (2018). Media Pembelajaran Inivatif dan Pengembangannya. Bandung: PT Remaja Rosdakarya.

Syifaunnur, H. (2015). Pengembangan Dan Analisis Kelayakan Multimedia Interaktif "Smart Chemist" Berbasis Intertekstual Sebagai Media Pembelajaran Kimia SMA. Universitas Negeri Semarang.

Thiagarajan, \& Sivasailan. (1974). Instructional development for training teachers of exceptional children: A sourcebook. Journal of School Psychology, $14(1), \quad 75$. https://doi.org/10.1016/00224405(76)90066-2

Trianto. (2014). Media Pembelajaran Terpadu: dalam Teori dan Praktek. Jakarta: Prenada Media Group

Warsita, B. (2008). Teori Belajar Robert M. Gagne dan Implikasinya pada Pentingnya Pusat Sumber Belajar. Jurnal Teknodik, 12(1), 64-78.

Winarno, M. E. (2014). Evaluasi Hasil Belajar Pendidikan Jasmani Olahraga 
p-ISSN : 2599-1418

Jurnal Pendidikan Ekonomi Undiksha

e-ISSN : 2599-1426

Vol. 12 No. 1 (2020)

dan Kesehatan. Malang: Universitas Negeri Malang. 